Winter 2016

\title{
Corporations and the Limits of State-Based Models for Protecting Fundamental Rights in International Law
}

David Bilchitz

University of Johannesburg; dibilchitz@uj.ac.za

Follow this and additional works at: https://www.repository.law.indiana.edu/ijgls

Part of the Human Rights Law Commons, International Law Commons, and the Political Theory

\section{Commons}

\section{Recommended Citation}

Bilchitz, David (2016) "Corporations and the Limits of State-Based Models for Protecting Fundamental Rights in International Law," Indiana Journal of Global Legal Studies: Vol. 23 : Iss. 1 , Article 7.

Available at: https://www.repository.law.indiana.edu/ijgls/vol23/iss1/7

This Article is brought to you for free and open access by the Law School Journals at Digital Repository @ Maurer Law. It has been accepted for inclusion in Indiana Journal of Global Legal Studies by an authorized editor of Digital Repository @ Maurer Law. For more information, please contact rvaughan@indiana.edu.

\section{$\Psi$}

JEROME HALL LAW LIBRARY

INDIANA UNIVERSITY

Maurer School of Law
Bloomineton 


\title{
Corporations and the Limits of State-Based Models for Protecting Fundamental Rights in International Law
}

\author{
DAVID BILCHITZ
}

\begin{abstract}
At the heart of international law lies a central tension. On the one hand, the fundamental rights recognized in international treaties protect the fundamental interests of individuals, obligating all actors who can affect these rights. One the other hand, international law has often been conceived of as a system in which the only legitimate actors are states. In turn, only states can be bound by the fundamental rights obligations in international treaties. To address this tension, two models have been proposed. The first is an "indirect duty" approach, whereby the state remains the primary duty-bearer and must itself "create" the obligations of nonstate actors. The second is an "expanded state" approach, which attempts to extend the idea of what falls within the domain of the state and includes the corporate sphere therein. I argue that neither succeeds. $I$ contend rather that the state should be conceptualized as having a "wholly public" character, whilst corporations are "partially public, partially private" entities. Fundamental rights push us to recognize that the state can no longer be conceptualized as the sole preserve of concerns that have traditionally been classified as "public," though it retains a distinct role from entities that have a private dimension. The "public" dimension of private actors such as corporations gives good reason to hold that they have direct fundamental-rights obligations under international law. That conclusion helps to chart the contours of a
\end{abstract}

* Professor, University of Johannesburg; Director, South African Institute for Advanced Constitutional, Public, Human Rights and International Law; SecretaryGeneral, International Association of Constitutional Law. I am grateful to Prof. Daniel Augenstein and Prof. Hans Lindahl for inviting me to participate in an intensive two-day colloquium on the topic "Global Human Rights Law and the Boundaries of Statehood," and I would also like to thank them and other participants for their comments which have helped to improve this article. I would also like to thank the highly professional editorial team of the IJGLS for their suggestions and excellent work on the article.

Indiana Journal of Global Legal Studies Vol. 23 \#1 (Winter 2016)

(c) Indiana University Maurer School of Law 
revised conception of statehood fit for the twenty-first century, where multiple overlapping forms of power impact upon the fundamental interests of individuals.

\section{INTRODUCTION}

International law, as traditionally understood, is a system set up by states to regulate the affairs between them. Since the Second World War, states have committed themselves in a variety of international instruments to ensuring that the fundamental rights of individuals are realized. 1 This has led to an understanding that individuals are the bearers of rights, and that states are the agents required to assume the obligations that flow from these entitlements. Such state obligations involve both duties to avoid harming rights (negative duties) as well as duties actively to take measures to help ensure these rights are realized (positive duties). ${ }^{2}$

This traditional understanding of the state's role in relation to fundamental rights ${ }^{3}$ has been challenged in this globalized world by the growth of a range of nonstate actors with the capacity to impact significantly upon fundamental rights. These include multinational corporations, nongovernmental organizations, and groups fighting in armed conflicts. These nonstate actors create a number of difficulties for the traditional view that states are the sole agents bound by fundamental-rights obligations. If the traditional view is correct, then

1. The United Nations Charter already recognizes that the protection of fundamental rights in the postwar world order is one of the key purposes of the United Nations. See U.N. Charter art. 1, para. 3.

2. As Henry Shue explains, "[t]he complete fulfillment of each kind of right involves the performance of multiple kinds of duties." HENRY SHUE, BASIC RIGHTS 52 (1980). This notion has been taken up in international human rights law with various United Nations Committees recognizing, for instance, that states have a range of duties to respect, protect, promote, and fulfill fundamental rights.

3. Throughout this article, I will generally use the term "fundamental rights" instead of "human rights," though the latter is the more familiar locution employed in international law. I prefer the term "fundamental rights," as it simultaneously indicates the foundational importance of the interests involved that these rights protect while avoiding what $I$ regard as a philosophical mistake of confining these rights only to humans. It is arbitrary to restrict such rights to humans if other sentient creatures also can possess many of these interests (as they do). For further elaboration on this, see David Bilchitz, Moving Beyond Arbitrariness: The Legal Personhood and Dignity of Non-Human Animals, 25 S. AFR. J. HuM. RTS. 38, 52.53 (2009) (“[F]aith-based notions with no philosophical grounding ... cannot be used to ground our legal rules in a secular constitutional democracy committed to a culture of justification."). I will only use "human rights" in situations where there is the name of a treaty, a quotation, or a term of art which cannot readily be replaced, such as "international human rights law." 
the discourse of fundamental rights should simply be inapplicable to nonstate actors.

In Part I of this paper, I go back to the foundational question of why fundamental rights are important. I argue that they matter primarily because they protect the fundamental interests of individuals. With our focus on the rights-bearer, the question of who bears the obligations in relation to rights must always be determined in relation to the primary goal of rights protection. That, I argue, in turn implies that rights place certain obligations on nonstate actors. The basic normative underpinnings of the idea of fundamental rights thus challenge the idea that solely the state is responsible for addressing these interests. The question then becomes how to reconcile this crucial element of rights reasoning with the traditional state-centric approach to international law.

In Parts II and III, I consider two different approaches to doing so with a particular focus on multi-national corporations (MNCs). The first, the "indirect duty" approach, attempts to extend the state-based model to cover nonstate actors in an indirect manner: the state remains the primary duty-bearer and must itself "create" the obligations of nonstate actors. I argue that this approach either fails to adequately capture the primacy of the rights-bearer or else collapses into a "direct duty" model. It also cannot adequately capture the universality of fundamental rights. The second, the "expanded state" approach, attempts to expand the idea of what falls within the domain of the state and includes the corporate sphere within that very domain. I argue that this approach undesirably elides the differences between agents. As such, it cannot adequately capture their distinctive natures or the implications this has for their consequent obligations.

A strict distinction is often made between the realm of the "public"which is often seen to embrace only the domain of the state--and the realm of the "private"- of which the corporate sector is regarded as an exemplar. In Part IV, I contend that this distinction should be conceptualized in a more nuanced manner: the state should be conceptualized as having a "wholly public character" whilst corporations are "partially public, partially private" entities. Fundamental rights push us to recognize that the state can no longer be conceptualized as the sole preserve of concerns that have traditionally been classified as "public," though it retains a distinct role from entities that have a private dimension.

In the Conclusion, I seek to bring these ideas together, concluding that there are good reasons to jettison both the "indirect duty" and "expanded state" models. Both models restrict obligations relating to fundamental rights to the state. However, both the normative 
underpinnings of fundamental rights and the "partially public" nature of the corporation provide good reasons to hold that corporations have direct fundamental-rights obligations under international law. That conclusion helps to chart the contours of a revised conception of statehood fit for the twenty-first century, where multiple overlapping forms of power impact upon the fundamental interests of individuals.

\section{Fundamental RightS AND THE STATE: LOOSENING THE BOND}

Traditionally, international law has been conceived of as a system in which states are the primary actors. States negotiate obligations that they voluntarily undertake through treaty commitments. Since 1945 , they have agreed to an extensive network of obligations to ensure the realization of fundamental rights. In this section, I explore a tension between the logic and normative underpinnings of fundamental rights, and the focus of international law on states as the sole actors.

Historically, the concept of fundamental rights developed as a protection for individuals against the overweening power of the state. The power imbalance between the state and the individual could lead to major intrusions on the freedom and well-being of the latter. This led philosophers to defend the notion that the state should be constrained to act only within boundaries that ensured the fundamental rights of individuals were realized. ${ }^{4}$ The first major legal document in this regard was the Declaration of the Rights of Man and of the Citizen. Enacted at the start of the French Revolution, the Declaration attempted to correct this imbalance. ${ }^{5}$ The document recognizes certain "natural and imprescriptible rights of man," which include "liberty, property, security and resistance to oppression."6 It provides guarantees against arbitrary imprisonment and the right to a fair trial. Importantly, it also guarantees freedom of expression. If we consider this latter right, we see a desire to protect the liberty of individuals to express their views against the potential power of state organs to censor any perspective regarded by public authorities as undesirable. In the eighteenth century this was a matter of deep concern, in that state power could be used to restrict the ability of individuals to express themselves against the threat of serious consequences. This remains an important concern in many parts of the world today.

Yet, what happens when that very liberty to express oneself is threatened not by the state but by another powerful but private actor?

4. See, e.g., John Locke, Two Treatises of Government para. 131, at 353 (Peter Laslett ed., Cambridge Univ. Press 1988) (1690).

5. See The Declaration On the Rights Of MAN AND Citizens [Fr.], 26 Aug. 1789.

6. Id. at art. 2. 
Consider, for example, a situation where a large corporation implements a policy that requires employees never to express their opinions without permission from the directors of the company, on pain of dismissal. The strong niche position of the company in the marketplace means that employees in this industry have little opportunities to find work elsewhere. Such a policy would pose a direct threat to the liberty of individuals to express themselves, but is not caused by a state body. It thus raises the fundamental question as to whether the right to freedom of expression places obligations not only on the state but also on private bodies such as corporations.

This question raises a foundational normative question as to why fundamental rights are important and what the point of protecting them is. Whilst I shall not provide an exhaustive discussion of various theories of fundamental rights, the example above highlights a matter of central significance. Individuals are concerned about fundamental rights because of certain foundational interests in liberty and well-being that rights safeguard. ${ }^{7}$ Freedom of expression, for instance, is valued as it protects an important interest individuals have in being able to freely express their views. ${ }^{8}$ That is why it is troubling for the state to wield its power to silence individuals. If that is so, however, then what matters is that the individual interest underlying the right to freedom of expression is protected. This logic, however, implies that it does not matter which agents threaten such freedom of expression: if an agent other than the state threatens this right, then that agent too must be prohibited from doing so.

Rights thus are guarantees that protect certain important interests that individuals hold dear. ${ }^{9}$ Rights, however, are important and are justified fundamentally because of the fact that they provide certain guarantees for the rights-bearer, who is the normative focus. ${ }^{10}$ Those

7. See, e.g., ALAN GEWIRTH, REASON AND MORALITY 63 (1978) ("Since the agent regards as necessary goods the freedom and well-being that constitute the generic features of his successful action, he ... implicitly makes a corresponding right-claim.").

8. Freedom of expression in turn may be defended for both instrumental and intrinsic reasons. For a famous treatise defending freedom of expression, see generally JoHN STUART MILL, ON LIBERTY (1859).

9. See, e.g., DAVID BILCHITZ, POVERTY AND FundaMENTAL RightS: THE JuSTIFICATION AND ENFORCEMENT OF SOCIO-ECONOMIC RIGHTS 217 (2000); MARTHA NUSSBAUM, WOMEN AND HuMan DEvelopment: THE CAPABIlities APPROACH 96-101 (2000) (arguing that political rights, when viewed as "combined capabilities," are valuable in their own right).

10. This feature has been the basis of criticism of rights discourse. Compare ONORA O'NEILL, TOWARDS JUSTICE AND VIRTUE 133-35 (1996) (criticizing rights discourse and proposing a moral perspective focused on obligations rather than rights), with BILCHITZ, supra note 9 , at 72-74 ("Talk of duties alone fails to indicate that it is our connection to others who have interests that is of critical importance and which imposes obligations upon us."). 
guarantees require various agents to take certain actions and refrain from others. It is thus crucial to consider the agents who bear the obligations flowing from these rights: different types of agents may in fact have distinctive obligations. Yet, in determining the obligations of agents, the focus on the rights-bearer remains primary. Various considerations must be canvassed in allocating obligations, including ensuring the effective realization of these rights and creating a fair distribution of responsibilities that takes into account the nature of each type of agent. To focus on only one type of actor-the state-is fetishistic in light of this logic, as there is no good reason why only the state should be the sole focus of rights obligations. If nonstate actors such as corporations imperil the realization of rights, we must consider how to ensure that the threat they pose does not materialize, and we must seek to determine their obligations in this regard.

Though the conceptual notion of fundamental rights historically developed in relation to the tyranny of states, the logic underpinning it requires a recognition of the obligations upon all actors that have the capacity to impact upon such rights. Since the Second World War, fundamental rights have been enshrined in a range of international instruments and form part of international law. The first important instrument that was developed in this regard was the Universal Declaration of Human Rights (UDHR) in 1949. The UDHR involved all the peoples of the world reaffirming "their faith in fundamental human rights, in the dignity and worth of the human person and in the equal rights of men and women."11 Of key importance is a commitment to secure the "universal and effective recognition and observance" of the rights in this declaration. ${ }^{12}$

International law has traditionally been understood only to recognize states as the key agents of international law with the capacity to create and assume fundamental-rights obligations. ${ }^{13}$ States, though, have accepted a foundational notion of international law-fundamental rights-that in its very logic requires recognition of the fact that all agents, whether state or nonstate actors, can be bound by the obligations they impose. There is thus an awkward co-existence that has developed between a nonstate-centric idea (fundamental rights) within a state-centric system (international law). How are we to conceive of the obligations of actors other than the state in relation to fundamental

11. Universal Declaration of Human Rights, G.A. Res. 217 (III) A, U.N. Doc. A/RES/217(III) (Dec. 10, 1948).

12. Id.

13. See JenNifer A. Zerk, Multinationals and Corporate Social Responsibility: LIMITATIONS AND OPPORTUNITIES IN INTERNATIONAL LAW 73 (2006) ("It was generally believed that only states could be 'subjects' of international law."). 
rights? In the next section, I discuss the first model, which has sought to square this circle: the "indirect duty" model.

\section{The State as Primary Agent and the State Duty to Protect}

\section{A. The Indirect Duty Model}

The traditional doctrinal response to the problem that nonstate actors can impact upon fundamental rights is to find a way to hold them accountable without giving up on the idea that the state is the primary agent bound by fundamental-rights obligations. The method of doing so involves expanding the scope of the state's obligations in relation to fundamental rights. The state not only assumes an obligation not to violate rights itself (the duty to respect) and to provide concrete goods (the duty to fulfill), but it is also required to ensure that other, nonstate actors do not imperil the interests protected by fundamental rights (the duty to protect). The state is thus responsible for imposing obligations on nonstate actors that they would otherwise not have in relation to fundamental rights and creating enforcement mechanisms to ensure they are realized. ${ }^{14}$ The contours of this duty are famously outlined in Velasquez Rodriguez v. Honduras:

An illegal act which violates human rights and which is initially not directly imputable to a State (for example, because it is the act of a private person or because the person responsible has not been identified) can lead to international responsibility of the State, not because of the act itself, but because of the lack of due diligence to prevent the violation or to respond to it as required by the Convention.... The State has a legal duty to take reasonable steps to prevent human rights violations and to use the means at its disposal to carry out a serious investigation of violations committed within its

14. See generally Stephen J. Emedi, Note, Utilizing Existing Mechanisms of International Law to Implement Human Rights Standards: States and Multinational Corporations, 28 ARIZ. J. INT'L. \& COMP. L. 629 (2011) (arguing that the state, despite the growing size and power of multinational corporations, still remains as the "actor that needs to be targeted to stop [multinational corporations] from violating human rights"); Aoife Nolan, Addressing Economic and Social Rights Violations by Nonstate Actors Through the Role of the State: A Comparison of Regional Approaches to the 'Obligation to Protect,' 9 HUM. RTS. L. REV. 225 (2009) (investigating the state's obligation to protect economic and social rights against third-party actors as interpreted by four different regional bodies). 
jurisdiction, to identify those responsible, to impose the appropriate punishment and to ensure the victim adequate compensation. ${ }^{15}$

This idea has been adopted by other regional human rights institutions and within the international treaty system. ${ }^{16}$ The state's duty to protect as understood in these international law instruments appears to comprise several elements. The traditional doctrine that states are the sole subjects or addressees of international law seems to imply that a nonstate actor such as a corporation would not have any obligations imposed by international human rights treaties. This appears to create a lacuna, in that corporations may then face no consequences for severe harms caused to individuals. To address this problem and ensure that rights are protected, the duty to protect requires states to take reasonable steps to ensure that third parties such as corporations do not violate such rights. I shall refer to this as the "indirect duty" view: whilst corporations, for instance, have no direct duties in relation to fundamental rights, they have such a duty indirectly through the state's framework of laws and regulations which protect such rights. The state's first duty is thus to set up the legal framework and regulatory structures that create obligations for third parties in relation to such rights. It must then adopt all the measures necessary to ensure enforcement of these laws, which must include an investigation and an enforcement system. The state is thus, under this conception, both the sole "originator" of obligations for third parties and the main "enforcer" of those obligations. The individual has no claim on a private actor, such as a corporation, outside the terms of a framework set up and established by the state itself.

15. Velásquez Rodríguez v. Honduras, Judgment, Inter-Am. Ct. H.R. (ser. C) No. 4, ๆ 172, 174 (July 29, 1988), available at http://www1.umn.edu/humanrts/iachr/b_11_12d.htm.

16. See Social and Economic Rights Action Centre (SERAC) and Another v. Nigeria, Comm. No. 155/96, 2001 AHRLR 60 para. 57 (ACHPR 2001) (citing Commission Nationale des Droits de l'Homme et des Libertés v Chad (2000) AHRLR 66A (ACHPR 1995)), available at http://www.chr.up.ac.za/images/files/publications/ahrlr/ahrlr_2001.pdf ("Governments have a duty to protect their citizens, not only through appropriate legislation and effective enforcement, but also by protecting them from damaging acts that may be perpetrated by private parties"); see also X and Y v. Netherlands, 91 Eur. Ct. H.R. (ser. A) (1985), available at http://hudoc.echr.coe.int/eng?i=001-57603; Gen. Comment No. 15: The Right to Water (Arts. 11 and 12 of the Covenant), Comm. on Econ., Soc. and Cultural Rights, 29th Sess., Nov. 11-Nov. 29, 2002, ๆๆ 23-24, U.N. Doc. E/C.12/2002/11 (Jan. 20, 2003), available at http://www.refworld.org/docid/4538838d11.html. 

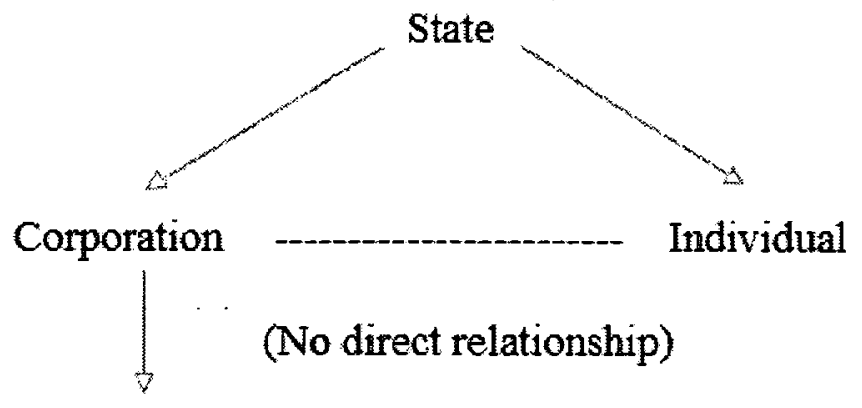

\section{Individual}

Fig. 1: The indirect duty relationship

\section{B. Critique of the Indirect Duty Model}

The indirect-duty view flows from particular assumptions about the need to regulate the impact nonstate actors can have on fundamental rights whilst retaining a state-based conception of international law. In engaging critically with it, I shall focus particularly on the idea that the state should be conceptualized as the "originator" of fundamental-rights obligations between private parties.

First, let us turn to internal problems in the very logic of the case for the indirect-duty view. ${ }^{17}$ States are tasked by international humanrights treaties to create the laws and regulatory frameworks that bind third parties in relation to fundamental rights. The question that arises is why states should bear any responsibility for regulating the behavior of third parties who are agents separate from the state. It is readily understandable why the state can be bound in relation to its own actions in relation to individuals, but why must it assume some responsibility for what others do or fail to do?

There are two types of answers that can be given in this regard: the first flows from the importance and nature of fundamental rights, the second from the very character and justification of the state itself (an idea that I will develop in the next section). As we have seen, in relation to the first answer, individuals, corporations, and nongovernmental

17. In the next few paragraphs, I attempt to elaborate and develop upon an argument made much more briefly in David Bilchitz, A Chasm Between 'Is' and 'Ought'? A Critique of the Normative Foundations of the SRSG's Framework and the Guiding Principles, in HuMAN Rights OBLIGATIONS OF BusINESS: BEYOND THE CORPORATE RESPONSIBILITY TO RESPECT? 107, 111-13 (Surya Deva \& David Bilchitz eds., 2013). 
organizations all have the potential to affect the individual interests protected by fundamental rights in serious ways. Since rights-bearers and their interests are primary, a system concerned with the protection of rights must place obligations on any actor that has the capacity to imperil or affect the realization of rights. The state duty to protect is one way of doing so, by placing obligations on the state to create binding legal frameworks and enforcement procedures that place obligations upon nonstate actors in relation to rights.

However, what is unclear is why we should follow an indirect route at all for recognizing that all agents are bound by fundamental rights. If the goal of rights-protection is to ensure the realization of rights, and multiple actors can impact upon such rights, why then not simply recognize that all actors who have the capacity to affect their realization are under direct obligations in this regard? The indirect-duty approach places the state between the individual and other actors, but it is simply unclear why this is necessary, efficient, or desirable. The problem with the indirect-duty view, then, is to see why it does not collapse into a direct duty view: if protecting the fundamental interests of individuals is the goal of rights-protection, then that would seem adequate to justify placing direct obligations on corporations and other nonstate actors. The doctrinal commitment to states as the sole subjects of international law appears rigid, unjustified, and unconnected to the very normative underpinnings of fundamental rights.

Moreover, it is hard to see why the state should have such a duty to protect at all, unless there is some pre-existing reason to believe that third parties are not entitled to violate the fundamental rights of individuals at will. If a concern to protect rights-bearers and their interests is at the foundation of fundamental-rights protection, then the reason for the state's involvement in this area must be the fact that private powerful parties can significantly affect the fundamental interests of other individuals. If that is the case, however, it is unclear why this does not in itself provide a sufficient reason for recognizing obligations upon those powerful private parties themselves in relation to other individuals.

This reasoning challenges the notion that the state should be recognized as the "originator" of the fundamental-rights obligations of nonstate actors. If the normative core of fundamental rights is the protection of individuals and their fundamental interests, then those rights are not created by the state but rather arise independently of the existence of the state. States themselves recognize these pre-existing rights in positive law (international or domestic), develop detailed regulations around them, and help develop institutional mechanisms to give effect to them. But they create neither the rights themselves nor 
the obligations flowing from them. Importantly, states-by signing the international treaties that protect fundamental rights-provide legal recognition for pre-existing moral rights, which they then undertake to give effect to in their national systems and in their actions of an international character.

The notion that the state is the "originator" of obligations for private parties also has a number of undesirable implications. First, the idea places the state in an extremely powerful position and suggests that it, in some sense, lies within its discretion as to whether to impose fundamental-rights obligations on third parties. ${ }^{18}$ The only reason the state is required to do so is the international obligations it voluntarily assumes in relation to other states. Yet, given the sovereign equality of states, it may (at least theoretically) withdraw from these obligations. If the state is the "originator" of fundamental-rights obligations for third parties, then it may refuse to create them. This state of affairs then leaves third parties to violate rights as they wish in the absence of state action.

It also raises the question as to the source of the very obligations of the state itself in relation to fundamental rights. Is the state the "originator" not only of the obligations of third parties but also of its own obligations? In what sense are its own obligations binding in this regard? Such obligations would stand on shaky ground if their only basis were the voluntary commitment of the state itself. This idea is also at odds with the recognition that it would be important to protect fundamental rights even if the state refused to bind itself to such treaties. The very idea of fundamental rights arises from the importance of individuals and the various characteristics that are fundamental to them. ${ }^{19}$ Individuals have these interests prior to the state recognition thereof, and their desire to have these rights protected is part of their

18. For a philosophical tradition that suggests this notion, see Jeremy Bentham, Anarchical Fallacies, in NONSENSE UPON STILTS 46, 69 (Jeremy Waldron ed., 1987) (accepting only legal positive rights recognized by the state and contending that natural rights make no sense- "from real laws come real rights"). It is quite unclear why Bentham objects to moral rights if they are understood as the claim that an individual "ought" to have certain legal rights. See Jeremy Waldron, Jeremy Bentham's Anarchical Fallacies, in NONSENSE UPON STILTS, supra, at 39-45; see also Amartya Sen, Elements of a Theory of Human Rights, 32 PHIL. \& PUB. AFF. 315, 324-28 (2004).

19. There are disputes in the philosophical literature as to which characteristics matter. See, e.g., JAMES GRIFFIN, ON HUMAN RIGHTS 149-58 (2008) (focusing on the importance of autonomy); JOHN RAWLS, A THEORY OF JUSTICE 90-95 (1971) (focusing on the importance of primary social goods); NUSSBAUM, supra note 9, at 96-101 (focusing on the importance of combined capabilities). 
reason for accepting state authority to begin with. ${ }^{20}$ Recognition of these rights, therefore, should not be seen as a choice of the state. The state's very normative legitimacy depends upon recognizing and giving effect to them. ${ }^{21}$ The state should thus not be understood to be the "originator" of fundamental-rights obligations. Rather, such obligations set the very goals of and constraints on legitimate state action.

A second major set of problems arises from the idea of the state as an "originator" of fundamental rights obligations. If the state fails to implement a legal framework that binds private parties, then the inference would be that corporations and other private actors lack any obligations in relation to fundamental rights. There are many parts of the world today in which states are weak or otherwise fail adequately to give effect to their duty to protect. In these parts of the world where there is a lack of regulation, it would seem then that powerful private actors are under no obligations in relation to the fundamental rights of other individuals. Yet, once again, this is wrong if fundamental rights attach to rights-bearers because of their inherent worth and dignity, and protect their significant interests.

The idea of the state as "originator" of fundamental-rights obligations undermines another key feature of fundamental rights: the fact that they universally apply to all individuals with those interests. ${ }^{22}$ If the state were the "originator" of fundamental-rights obligations, such obligations might well fail to be recognized universally. Moreover, a state that failed to create such obligations could not justifiably be held liable for any fundamental-rights violations. Such a doctrine would also preclude liability before any national or international tribunal for violations of fundamental rights by private actors who acted in jurisdictions that failed to impose fundamental-rights obligations on them. The universality of rights protection will also be undermined by this idea in that different states will "create" different legal frameworks that impose different obligations on private actors. Such a scenario would be extremely undesirable in that it would lead to a situation in which corporations would have certain fundamental-rights obligations in some states and not others. In some cases, this would lead to a situation in which corporations lack important obligations, placing rights in jeopardy. That would fail to address the key goal of

20. This idea is deeply rooted in the social contract tradition of philosophy. See, e.g. Locke, supra note 4; see also JEAN-JACQUES RoUSSEAU, THE SOCIAL CONTRACT 27-30 (Charles Frankel trans., Hafner Pub. Co. 1947) (1762).

21. See Frank I. Michelman, Socioeconomic Rights in Constitutional Law: Explaining America Away, 6 INT'L J. CoNST. L. 663, 675-76 (2008) (explaining how the Rawlsian theory of legitimacy explicitly applies in the context of fundamental rights).

22. See JACK DONNELLY, INTERNATIONAL HUMAN RIGHTS 18 (2d ed. 1998). 
fundamental-rights protection outlined above, namely, to ensure protection for the fundamental interests of individuals.

Indeed, this is not just a theoretical problem that could arise. With the advent of globalization, many corporations shifted their manufacturing operations to countries (such as China) and regions (such as Southeast Asia) where minimum labor rights and standards were not incorporated into labor laws. The lack of these protections has led to exploitation and misery for many workers. ${ }^{23}$ Yet, the multinational corporations in question might argue that, since these countries have not created labor protections for their workers, the corporations have done nothing wrong and have not violated any fundamental rights, as they lack any obligations in the absence of state regulation. An understanding of the impact of their activities on the fundamental interests of workers would, however, testify otherwise. The universality of international fundamental rights thus requires recognizing that there are common standards applicable across the globe, and that international fundamental rights can be violated by corporations even in circumstances where states have failed to implement adequate national legal frameworks to grant them recognition.

A variant of this problem arises from the manner in which the duty to protect has been conceptualized in international law. The duty requires the state, when setting up legal frameworks and enforcement mechanisms, to exercise reasonable due diligence to ensure that third parties do not violate the rights of individuals. State liability is thus not absolute in relation to third parties, as seems fair: the state cannot completely control the actions of all nonstate actors. Moreover, if the state were the originator of such obligations, it would need to establish a rather exhaustive set of requirements for such actors if it is to exercise its powers effectively. The possibility, however, exists that a corporation, for instance, will violate rights in a new and unexpected manner, despite the reasonable actions of the state in developing a legal framework to regulate corporate behavior. In such a scenario, victims of the rights violations may not be able to show that the state has been unreasonable in its actions. However, if the corporate behavior has not been proscribed by existing legal regulations, then it could also not be challenged, as it lacks any direct obligations other than the ones imposed by the state. The only way to solve this problem is to avoid conceptualizing state action as being the "originator" of corporate

23. See generally Bin Wu \& Yongniang Zheng, A Long March to Improve Labour Standards in China: Chinese Debates on the New Labour Contract Law, 39 CHINA BRIEFING SERIES (2008) (U.K.), available at http://www.nottingham.ac.uk/cpi/ documents/briefings/briefing-39-china-new-labourcontract-law.pdf. 
obligations in the first place, and to recognize that fundamental rights at the international level directly place obligations upon corporations, these obligations being amenable to application in new scenarios where the underlying interests are affected negatively.

The discussion thus far also highlights an important relationship between a normative obligation and the right to an effective remedy. The right to a remedy is recognized as a self-standing right in international human rights law. ${ }^{24}$ At the same time, the right to a remedy is in some sense derived from a prior recognition of obligation: one can only acquire a remedy if a prior duty has been breached. The duty to protect once again suggests that the only remedies that lie against corporations for wrongs they commit in relation to fundamental rights can arise from obligations that particular states have created in their laws and regulatory frameworks. The ability to access a remedy thus becomes contingent upon the relative strength of the laws in particular states. Scant possibilities for a remedy are offered to victims of rights violations living in states that have not recognized corporate obligations for rights violations.

Indeed, this lacuna exists within the UN Guiding Principles on Business and Human Rights. ${ }^{25}$ The Guiding Principles rest on three pillars: the state's duty to protect individuals from rights violations by corporations; the corporate responsibility to respect and avoid harm to the rights of individuals; and the importance of having access to a remedy for victims of rights violations. The corporate responsibility to respect, however, is expressly understood in the document as not being a legal responsibility. ${ }^{26}$ Yet, the access-to-remedy pillar recognizes the importance of legal remedies where the rights of victims have been violated. The framework thus operates as follows: since corporations have no direct legal obligations to individuals, no legal remedy can be claimed against them unless the state has created obligations for corporations and these obligations are breached. Once again, this leaves individuals without a remedy against the perpetrator of the violations in circumstances where the state fails to regulate and create such obligations.

24. See G.A. Res. 217 (III) A, supra note 11, art. 8; International Covenant on Civil and Political Rights, G.A. Res. 2200A (XXI), art. 2(3), U.N. GAOR, Supp. No. 16, U.N. Doc. A/6316 (Dec. 16, 1966), available at http:/www.ohchr.org/en/professionalinterest/pages/ ccpr.aspx.

25. See Special Representative of the Secretary-General, Guiding Principles on Business and Human Rights: Implementing the United Nations Protect, Respect and Remedy' Framework, U.N. Doc. A/HRC/17/31 (Mar. 21, 2011) (by John Ruggie).

26. See id. at 13-14 ("The responsibility of business enterprises to respect human rights is distinct from issues of legal liability and enforcement, which remain defined largely by national law provisions in relevant jurisdictions."). 
I have argued that there is good reason to jettison the idea implicit in the indirect-duty model that states are the "originators" of the obligations of private actors in relation to fundamental rights. This argument should not be misconstrued as an argument against the state's development of detailed positive regulations governing the relationship between corporations and other private actors. It simply means that corporate obligations in relation to fundamental rights precede and must guide such regulation. The moral character of fundamental rights predates the state, and their legal normativity flows both from this moral source as well as from the nearly universal recognition of fundamental rights as law at the international level by states.

\section{EXPANDING THE STATE}

I have considered some of the difficulties with an indirect-duty view of the fundamental-rights obligations of corporations as well as the conception of the state that it assumes. If we wish to modify or reject this approach, what are the alternatives? The possibility I consider in this section seeks to retain the traditional approach of international law by conceiving of the state as the primary subject and bearer of obligations. However, it attempts to address some of the challenges discussed above by expanding our understanding of what, in fact, constitutes the state. This approach includes nonstate actors within the domain of the bearers of obligations in respect of fundamental rights by virtue of reconceptualising them as part of the state itself (and thus as state actors).

\section{A. Private Entities as Part of the State}

To understand this approach, it is instructive to consider the AllPay case $^{27}$ decided recently by the South African Constitutional Court. An agency of the South African government issued a tender that required bidders to propose methods whereby social grants would be paid to individuals. These grants are relied upon by over fifteen million socially vulnerable people as their means of living. One tenderer, Cash Paymaster, was awarded the grant and began to deliver the services. An unsuccessful tenderer, AllPay, challenged the tender award based on

27. There were two judgments in this case. See AllPay Consol. Inv. Holdings v. Chief Exec. Officer of the South African Social Security Agency 2014 (1) SA 604 (CC) (S. Afr.) (dealing with validity of the tender itself); AllPay Consol. Inv. Holdings v. Chief Exec. Officer of the South African Social Security Agency 2014 (4) SA 179 (CC) (S. Afr.) (dealing with the appropriate remedy). 
various irregularities in the tender process. The Constitutional Court found that these irregularities did in fact render the award of the tender to Cash Paymaster invalid. ${ }^{28}$ A major difficulty in this case, however, arose as to the remedy the court should grant. If Cash Paymaster's services were to have been terminated, millions of people could be placed at risk of not receiving their social grants. The court in the end decided that, despite the invalidity of the tender, Cash Paymaster was under an obligation to continue to provide the payment services it offered.

The court reasoned that, whilst Cash Paymaster was a private company and not under the control of the state agency in question, "the function that it performs - the country-wide administration of the payment of social grants - is fundamentally public in nature."29 The public nature of this function and its importance meant that, for purposes of this contract, Cash Paymaster had become an organ of state:

When Cash Paymaster concluded the contract for the rendering of public services, it too became accountable to the people of South Africa in relation to the public power it acquired and the public function it performs. ${ }^{30}$

The South African Constitutional Court here effectively reclassifies the boundaries of the state to include private companies that are performing public functions. Similar judgments and approaches can be found in other jurisdictions. ${ }^{31}$ Under this model, corporations that had

28. Allpay 2014 (1) SA 604 (CC) at para. 93.

29. Allpay 2014 (4) SA 179 (CC) at para. 52.

30. Id. at para. 59 .

31. See, e.g., R v. Panel on Take-overs and Mergers, ex parte Datafin PLC [1987] 1 QB 815 (Eng.); Murray Hunt, Constitutionalism and the Contractualisation of Government in the United Kingdom, in THE Province of ADMINISTRATIVE LAW 21, 28 (Michael Taggart ed., 1997) (describing ex parte Datafin PLC); see also Stephen Ellmann, A Constitutional Confluence: American "State Action" and the Application of South Africa's Socioeconomic Rights Guarantees to Private Actors, 45 N.Y.L. Sch. L. Rev. 21 (2001) (discussing state action doctrine jurisprudence in the United States). Compare McKinney v. Univ. of Guelph, [1990] 3 S.C.R. 229 (Can.) (emphasizing the presence of governmental control in Canada's state action doctrine), and Stoffman v. Vancouver Gen. Hosp., [1990] 3 S.C.R. 48 (same), with Eldridge v. B.C. (Att'y Gen.), [1997] 2 S.C.R. 624 (holding that a failure to provide medical interpreter services for the deaf does not violate the Canadian Charter of Rights and Freedoms). A similar approach has been adopted by the European Court of Human Rights in several cases too. See, e.g., Yershova v. Russia, App. No. 1387/04, 2010 Eur. Ct. H.R. 1; Woś v Poland, App. No. 22860/02, 2006 Eur. Ct. H.R. 1; Novoseletskiy v. Ukraine, App. No. 47148/99, 2005 Eur. Ct. H.R. 1; Radio France v. France, App. No. 53984/00, 2004 Eur. Ct. H.R. 1; Costello-Roberts v. United Kingdom, App. No. 13134/87, 
conceived of themselves as private actors are transformed into public actors with concomitant direct obligations to individuals.

Such a model offers a response to the growth of powerful nonstate actors within the traditional state-centric approach to international law. To address the obligations of these nonstate actors in relation to fundamental rights, we simply reconceptualise the nonstate actors (or their functions that have an impact on fundamental rights) as essentially public in character and thus as part of the state.

This model can be represented in a simplified form pictorially: ${ }^{32}$

\section{State \\ Private Entities}

Fig. 2: The "Expanding State" Model

\section{B. Is the Expanding-State Model Desirable?}

It is true that, increasingly, corporations are performing functions traditionally assumed by the state. ${ }^{33}$ The question then arises as to

1993 Eur. Ct. H.R. 1. The European Court of Justice has also extended the responsibility of the state in a like manner in Case C-188/89, Foster v. British Gas PLC, 1990 E.C.R. I3313. For the European context, see the report by DANIEL AUGENSTEIN, STATE RESPONSIBILITIES TO REGULATE AND ADJUDICATE CORPORATE ACTIVTTIES UNDER THE EUROPEAN CONVENTION ON HUMAN RIGHTS (Apr. 2011), available at https:/pure.uvt.nl/ portal/en/publications/state-responsibilities-to-regulate-and-adjudicate-corporateactivities-under-the-european-convention-on-human-rights\%2866a00461-6af6-419e-8c4d55a930818438\%29.html.

32. Variants of this model might recognize some private entities as separate from the state but having no obligations to individuals.

33. There is an expanding body of literature considering this question. See, e.g., Roberto Unger, LAW IN Modern Society 193 (1976); Stephen Sedley, Foreword, in The 
whether it is desirable-for purposes of recognizing obligations upon corporations for fundamental rights-to reconceptualise them as wholly public entities in this way. I argue that this approach should not be adopted for several reasons.

First, the decision relating to how far the scope of the state extends is extraordinarily complex. Many states have multiple relationships with various forms of corporate actors. For example, several corporations today run prisons, a function that would traditionally be at the heart of the state's responsibility to enforce its laws. In terms of the functional test outlined by the South African Constitutional Court, it would indeed seem that such corporations become part of the state for purposes of exercising those functions. However, let us imagine that the state retains control of several prisons but employs a private catering company to provide meals for prisoners. Prisoners, as a dependent group, are wholly reliant upon the food provided to realize their right to food. Is the catering company now an organ of state? This line of reasoning could be expanded to include any company that contracts with the state to provide a service. Is the mere conclusion of a contract with a state sufficient to render the contracting entity "public" for that purpose?

It is possible to adopt an even more expansive conception of the domain of the public. Every corporation is in fact constituted by laws passed by the state in which it is incorporated. These laws also regulate the operations of the corporation. Since the laws of the state enable the very creation of corporate entities, it is arguable that all such entities are in fact created by the public sphere and thus are part of the state itself. Such reasoning challenges the entire division between a "private corporate sphere" and a "public state sphere."

Such reasoning could be extended even further. The domain of law does not only regulate corporations. It also specifically determines the background rules in terms of which all individuals live and conducts their lives. Whilst individuals have a clear existence independent of the state, their daily actions and abilities are constrained and enabled by the state. We could thus argue that individuals too are essentially "part" of the state and have obligations to one another as a result.

This reasoning, in some sense, appears to constitute a reduction $a d$ absurdum: the state will encompass everything affected by it. Moreover,

Province of Administrative LaW vii (Michael Taggart ed., 1997); Geoff Budlender, Faculty of Law, University of Stellenbosch, 20 Years of Democracy: The State of Human Rights in South Africa (Oct. 2, 2014), available at http://blogs.sun.ac.za/law/files/ 2014/10/Annual-Human-Rights-Lecture-2014-Adv-GBudlender-SC.pdf; Meghan Finn, Organs of State: An Anatomy, 31 S. AFr. J. HUM. RTS. 631 (2015) (discussing when private entities constitute an organ of state). 
if individuals are part of the state, then the very notion of obligations in relation to fundamental rights becomes problematic: ultimately, an obligation of the state towards an individual will be an obligation of the state towards itself. Such a result would be normatively undesirable in that it would start abstracting from the real reasons for rights protection: that individuals are distinct entities with distinct interests who are not subsumed by any entity such as the state. The notion of state obligations to itself would obscure the key normative issues involved.

The logic of attempting to capture the obligations of nonstate actors for fundamental rights through expanding the conception of the state could well lead to this absurd result of including every agent within the domain of the state. If a more reasonable model were to be adopted which drew the line less expansively, then a justification would need to be provided as to why the boundaries of the state only extend so far and no further. What is necessary is an account of the nature and functions of particular entities, and whether they share some of the chief characteristics of the state.

\section{Reconceiving the "PUblic": Corporations as Partially PUblic ENTITIES}

A brief sketch of a less expansive model will demonstrate the undesirability of collapsing the corporate sphere into the state. In order to do so, we need to draw on an account of the nature of the state itself and its underlying justification. I will rely on social-contract theory, rooted in the idea that the state is formed by a social contract between those who live within it, which grants the state legitimacy to pass laws and regulations and exercise powers of enforcement over others. This idea has a long history. Hobbes famously imagined a state of nature where, in the absence of a sovereign power, individuals live in a state of war against one another that renders life "nasty, brutish and short." 34 To avoid such a situation, individuals consent to the existence of a sovereign power in order to attain a state of peace between them, to preserve their own lives, and to "be protected against other men." 35

Locke has a different vision of the state of nature, but it is similar to Hobbes's in one crucial respect: in the state of nature, individuals lack an impartial body to adjudicate disputes and to enforce the settlements

34. Thomas Hobbes, Leviathan 89 (Richard Tuck ed., Cambridge Univ. Press 1991) (1651).

35. Id. at $92,120-21$. 
arrived at. ${ }^{36}$ It is necessary to form a neutral body that exercises an impartial adjudicatory and enforcement power between people and is constrained by the need to protect the natural rights of life, liberty, and property. ${ }^{37}$ On both views, it is important to recognize that the individual is (at least initially) primary and contracts into the state. Moreover, both views (though to different degrees) place limitations on the power of the state. For Hobbes, the individual may resist any command to "kill, wound or mayme himself; or not to resist those that assault him; or to abstain from the use of food, ayre, medicine, or any other thing, without which he cannot live";38 for Locke, the state cannot imperil an individual's life, liberty, or property. ${ }^{39}$

Both these ideas are connected to the notion that one of the key reasons for the existence of the state is to ensure the peaceful enjoyment by individuals of certain fundamental rights. The state is empowered to develop laws that are impartial between persons, and must be founded on the idea that each individual is of equal importance. 40 The equal importance of individuals requires that the most important interests implicated in securing their "worth" or "importance" be protected. ${ }^{11}$ Part of the very justification for the state itself is the state's power to ensure that the relationships between private parties do not violate the fundamental rights of others, conform to certain basic standards, and do not imperil the material well-being of other individuals. ${ }^{42}$ Individuals thus grant the state the powers of regulation and enforcement to the extent necessary to ensure the realization of their fundamental rights. The state's very raison d'être involves regulating the relationship

36. See LoCKE, supra note 4, para. 13, at 275 ("[I]t is unreasonable for Men to be Judges in their own Cases.").

37. See id. at para. 123, at 350 ("[Man in the State of Nature] seeks out . . . to unite for the mutual Preservation of their Lives, Liberties and Estates, which I call by the general name, Property").

38. HoBBES, supra note 34 , at 151 .

39. See LOCKE, supra note 4 (“[T] he power of the Society, or Legislative constituted by them, can never be suppos'd to extend farther than the common good.").

40. See Ronald Dworkin, SOVEREIGN VirTuE: THE THEORY AND Practice of EQUALITY 1 (2000) ("No government is legitimate that does not show equal concern for the fate of all those citizens over whom it claims dominion and from whom it claims allegiance.").

41. See BILCHITZ, supra note 9, at 64-65.

42. It should be recognized that neither of these social contract theories supports the idea that states should simply abstain from interfering with private parties as some recent libertarian theorists argue. The very reason for the existence of the state provides grounds for the prevention of harm, but also for protecting individuals from private violence and ensuring that individuals have a certain level of material well-being, which may itself require interference with the property rights of others. See, e.g., ROBIN L. WEST, RE-IMAGINING JUSTICE 84-85 (2003). 
between private parties inter se to ensure that they live together in such a way that the rights of each are realized (to the extent possible).

This reasoning has important implications for fundamental rights and the role of the state. It is evident from social-contract theory that the state is not the "originator" of obligations in relation to fundamental rights (as was suggested by the indirect duty model). On the contrary, such obligations are its very reason for coming into being. Central to this argument is the idea that the state is an entity that is wholly public in nature: its foundation and legitimacy lie in its impartiality and its treatment of each individual with equal importance. As such, the state is not meant to disclose preferences for the interests of particular persons, but must exercise its powers in a general way for the purposes it was formed without disclosing favoritism or bias to any particular person. ${ }^{43}$ In this way, the state can achieve the goals social-contract theorists had in mind for it: preserving the peace between people and creating an impartial enforcement arm to adjudicate disputes between persons. ${ }^{44}$

If this wholly public nature is the key characteristic of the state, then not all entities and individuals can be assimilated into the structure of the state itself. The state should not act in ways that favor the interests of particular persons, but individuals within a society are of course permitted to do so (within certain constraints). How then are we to conceive of corporations? I contend that they must be understood as entities with a dual nature: from the point of view of the state, the reason it enables corporations to be founded in law must be that such an entity will bring positive benefits to the society. There is thus a social purpose at the heart of the corporation. ${ }^{45}$ However, that social purpose

43. This view has garnered widespread support by philosophers, although it is given different justifications. See, e.g., AMARTYA SEN, INEQUALITY REEXAMINED 17-18 (1992) ("A theory may accept . . . inequality . . . , but in defending those inequalities it would be hard to duck the need to relate them, ultimately, to equal consideration for all in some adequately substantial way."); Ronald Dworkin, Comment on Narveson: In Defense of Equality, 1 SOC. PHIL. \& POL'Y 24, 33 (1983).

44. As we have seen, these represent the views of Hobbes and Locke. See generally, HOBBES, supra note 34; LOCKE, supra note 4.

45. See, famously, E. Merrick Dodd, Jr., For Whom are Corporate Managers Trustees?, 45 HARV. L. REv. 1145, 1148 (1932). But see, A. A. Berle, Jr., Corporate Powers as Powers in Trust, 44 HARV. L. REV. 1049, 1074 (1931) (arguing that "all powers granted to a corporation . . . are necessarily and at all times exercisable only for the ratable benefit of all the shareholders" - a position from which Berle, who would later accept Dodd's view, would cease to argue); Milton Friedman, The Social Responsibility of Business is to Increase its Profits, in ETHICAL THEORY AND BUSINESS 51 (Tom L. Beauchamp et al., eds., 8th ed. 2009) (opining that a corporation has no social responsibility to the public; the shareholders drive the corporation's social responsibility). It is hard, though, to see how 
is to be realized in a particular way: the state enables individuals to form an entity with distinct characteristics-separate legal personality, limited liability, and perpetual succession ${ }^{46}$-for reasons relating to their own self-interest. Individuals form corporations as a vehicle to maximize their own benefits, in particular by limiting their liability against the risks of doing business. The underlying idea is that individuals may be prepared to take more risks and innovate more if they are not exposed to the possibility of personal insolvency. Individuals are thus empowered to conduct business for their own selfinterest in a manner that is meant to have positive and beneficial social effects. The corporation is thus a vehicle for individual entrepreneurship and self-interest to be harmonized with public social and economic goals. ${ }^{47}$ The corporation is to be understood in this way as a "partially private, partially public" entity. To insist that corporations are simply public entities without recognizing their private dimension is to fail to capture the very nature of the entity in question, and could well frustrate the very beneficial social effects they are meant to have. At the same time, to contend that the corporation is entirely private in nature fails to recognize the important social purpose behind its creation, and its entanglement in a web of relations and effects that do not simply impact upon the owners of the corporation.

If corporations were simply a part of the state, then they would be subject to all the obligations that the state has. Thus, we would legitimately ask the question whether corporations had duties to provide the infrastructure for voting, to ensure an effective criminal justice system, and to provide health care for all. ${ }^{48}$ It may be responded that this is absurd and would not necessarily be entailed by recognizing corporations as part of the state: just as different parts of the state have different functions and obligations, so too could corporations and their

the state could legitimately enable the creation of an entity if there were no social purpose to its creation.

46. See, e.g., Henry Hansmann \& Reinier Kraakman, What is Corporate Law?, in THE ANATOMY OF CoRPORATe LaW: A Comparative and FunCtional APPROaCH 7, 7 (Reinier Kraakman et al. eds., 2004).

47. See David Bilchitz, Do Corporations Have Positive Fundamental Rights Obligations?, 57 THEORIA 1, 9-11 (2010) (describing the dual nature of the corporate entity and its implications for the positive obligations of corporations in relation to fundamental rights); see also FLoRIAN WETTSTEIN, MUlTi-National CoRPorations aND GLOBAL JUSTICE: HUMAN RIGHTS OBLIGATIONS OF A QUASI-GOVERNMENTAL ORGANISATION 324-25 (2009) (describing ways in which corporations should help the world's poor gain access to basic infrastructure, facilitate the creation of effective social policies, and engage with the provision of public goods and social services).

48. For an articulation of this worry, see JOHN GERARD RUGGIE, JUST BUSINESS: Multinational CORPORATIONS AND HUMAN RIGHTS 51 (2013). 
distinctness be captured in this way. ${ }^{49}$ Yet, clearly, such a view would require an account of why corporations have particular obligations and not others. Conceiving of them as entirely public in nature causes particular problems for this project. One of the key distinctions between corporations and the state is that corporations are entitled to act in a partial way to further their own interests, as opposed to always having to act in the general interest. Whilst constraints may be placed upon the extent to which a corporation can act in its self-interest, and whilst it may be required to contribute to the general weal, one of the key reasons underlying the creation of the corporation is to enable the individual self-interest underlying its creation ultimately to have social benefits. To conceptualize the corporation as fundamentally public in nature fails to capture a part of its essential nature, namely, that its very existence arises from the fact that private motives can create public benefits. ${ }^{50}$

Moreover, part of the reason for distinguishing between the public and the private in liberal political theory lies in the idea that the private sphere is one in which individuals may have a certain level of autonomy to determine the course of their own lives. It is recognized that individuals may legitimately pursue their own ends (within certain constraints) and that this is the hallmark of a free society. ${ }^{51}$ They need not always operate neutrally, impartially, or with a public purpose in mind; these are characteristics of the public sphere. The corporation was conceived as a vehicle for individuals to pursue their business interests, which would otherwise have been pursued through other forms (such as sole proprietorships or partnerships). The success of the corporate form lies in the particular advantages it offers individuals in their entrepreneurial activities: limited liability and perpetual succession, for instance, have significant benefits for shareholders that are not available in other business forms. It is also legitimate to recognize the fact that the corporation itself is created through law,

49. One of the worries here is that the blurring could lead the state to attempt to avoid realizing its own obligations and seek to transfer them to the corporate sphere undermining "domestic political incentives to make governments more responsive and responsible to their own citizenry." Id. at 52.

50. Capitalist economic theory suggests that a market consisting of rational and selfinterested individuals with an adequate level of competition will naturally allocate resources efficiently. Effectively, a competitive market will ensure that capital will be directed to those enterprises that produce products for which the public has demand. In this way, the public benefits by being able to purchase desired products at the lowest possible price whilst ensuring that producers remain profitable. See DAVID BEGG ET AL., ECONOMICS 260-1 (8th ed. 2005) (explaining economic concepts of perfect competition and Pareto efficiency).

51. John RaWLS, Political Liberalism 30 (1993). 
which renders it more public in nature than the other forms of business enterprise. At the same time, it does not fundamentally lose its character as an entity that individuals employ to express their autonomy in the sphere of business. As such, space must be preserved for the exercise of this autonomy separate from collective and public goals. To collapse the public and private spheres would be to subsume the individual into the collective rather than to preserve the complex interplay between the two, which is characteristic of the corporate entity.

\section{CONCLUSION: FUNDAMENTAL-RIGHTS OBLIGATIONS BEYOND THE STATE}

In Parts II and III, I discussed the shortcomings of two models through which international law might impose duties on corporate actors, and which attempt to preserve its traditional state-based focus. The "indirect duty" model fails conceptually and practically to preserve the primacy and universality of rights by reifying the state as the sole addressee and "originator" of fundamental-rights obligations. The "expanded state" model attempts to recognize that entities other than the state can indeed have wider public responsibilities in relation to fundamental rights, but it does so by eliding the distinction between the state and those other entities.

What causes the problem in these models is the attempt to retain the view that the state is the sole agent responsible for realizing fundamental rights. I argue that the logic of fundamental rights essentially requires dispensing with this assumption and allowing the beneficiary of rights to become the focus, with all agents capable of violating such rights as potential bearers of obligations with respect to them. For the effective allocation of obligations, we need a model that can recognize the distinctive nature of the agents that can impact upon fundamental rights. The very nature of these agents may provide good reasons why they should have obligations in relation to fundamental rights. My focus in this paper has been on the corporation, although the reasoning may be applicable to some other nonstate actors.

As I argued in Part IV, it is important to recognize the dual character of the corporation. It is an entity created through law with the goal of achieving social benefits (its "public dimension"); yet the entity itself is successful only insofar as it retains an ability to express individual self-interest and autonomy in conducting business in the best way possible to ensure satisfactory profits (its "private dimension"). Any adequate attempt to conceptualize the obligations of the corporate entity must do justice to these two features. 
The public dimension of the corporation compels the conclusion that it has some obligations in relation to fundamental rights. Since it is an entity created for purposes of achieving social benefits, and created through law, it must not harm the most fundamental constitutional entitlements enshrined in law, which guide the very legal system itself. In this regard, the corporation can be recognized to have negative obligations. It may also be required to act in specific ways so as to achieve these goods; in this regard, it may have positive obligations as well. The private dimension of the corporation, however, places constraints on how much may be required of it. If it were permanently to become a loss-making entity acting in the public interest, then its "private" character would be lost and the corporation would be subsumed into the state. ${ }^{52}$ We thus see that it is not only the potential impact of corporate activities on fundamental rights but also the very nature of the corporate form that justifies the recognition that it bears obligations in this regard.

Such a multi-agent model of obligations may be depicted as follows:

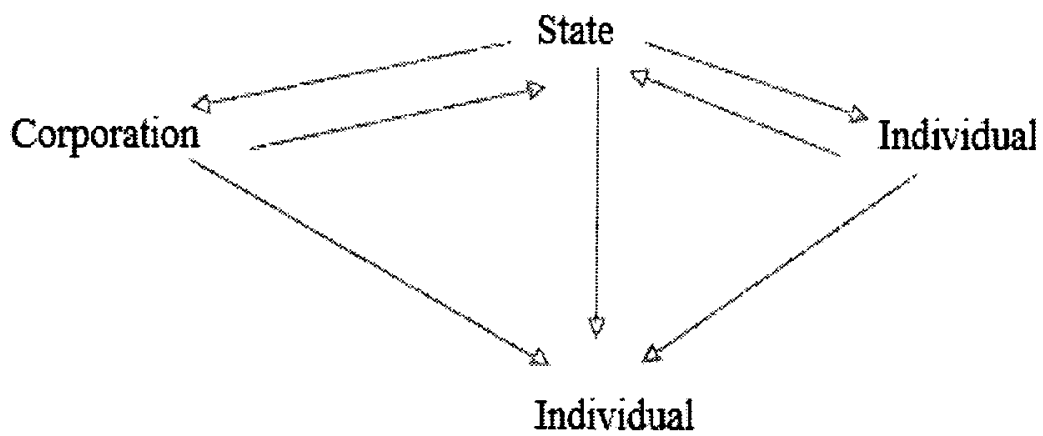

Fig. 3: Multi-agent model of fundamental rights obligations

On this model, the individual is primary and all agents have some obligations towards individuals in relation to fundamental rights. Importantly, this model does not permit a firm distinction between "private" and "public" entities, although it recognizes that the state, the

52. For a further discussion of these ideas, see Bilchitz, supra note 47, at 23-26. Determining the exact boundary of what may be required by the "public" dimension of a corporation lies beyond the scope of this paper, which simply aims to demonstrate the fact that such obligations exist. 
corporation, and the individual are distinct agents and entities with distinct obligations. It is important to understand why this is so.

Being an entity with obligations in relation to fundamental rights has a number of important consequences. It means that the entity in question is not entitled in all circumstances to privilege its own selfinterest over others and must seek to consider its effect on the rights of others as placing important constraints on what it may do. In this sense, any entity that has direct rights obligations cannot be wholly selfregarding and has a duty to consider its impact on fundamental rights in an impartial manner. This kind of reasoning would usually be characteristic of what is required of the state; however, the potential for an impact on fundamental rights renders a private entity-at least in that respect-partially public. At times, there may be a conflict between its private and public dimensions. Decisionmaking procedures common in public law such as a proportionality enquiry may be necessary to determine whether the private interests would provide legitimate reasons to restrict the rights of others. ${ }^{53}$

This reasoning suggests that there is a continuum of what is often taken to be characteristic of the public: impartial consideration of the interests of all parties with legitimate interests. At the same time, in relation to some agents, autonomy and self-interest are legitimate bases upon which they may act, and thus not all of their actions need be guided by the demands of impartiality. Each agent contains in itself an element of the "public" as conceived in this manner, although to differing degrees. This is what renders the "expanded state" model attractive yet ultimately flawed: its failure to recognize that some entities need not wholly be guided by impartial considerations.

If the domain of the public-impartiality, rights, obligations, and distributive justice - is not the sole preserve of the state, what is the implication of this conception for the state's distinctive role? Importantly, as I argued, in relation to nonstate actors, the "public" is a matter of degree; the state, however, has no dimension that is legitimately characterized as "private." 54 Thus, the state is no longer to

53. For an attempt to articulate such an approach, see David Bilchitz \& Laura Ausserlandscheider Jonas, Proportionality, Fundamental Rights and the Duties of Directors, OXFORD J. LEGAL STUD. (forthcoming 2016).

54. The state in recent years has formed private corporate entities (public enterprises) that often operate in a manner more characteristic of private corporate entities: in South Africa, these include the airline, South African Airways, and the transport authority, Transnet. There may of course be a legitimate question as to whether the state should be involved in a particular sector. Once it is decided that the state should be involved, however, the entity may operate according to certain business principles but, ultimately, its goal must be public in nature, seeking to advance the interests of all in a particular political community. 
be conceived of as the only public entity but as the only wholly public entity. The state may not legitimately take the private interests of any particular grouping as a purpose it seeks to achieve. Rather, its foundation lies in impartiality and the treatment of each individual with equal importance. Similarly, the state may only legitimately seek to limit fundamental rights for purposes that are fundamentally public and that will seek to benefit all individuals within its domain. The wholly public nature of the state provides a justification for its regulatory power as well as a constraint on the operation of such power. The fact that the state is mandated to govern impartially in the interests of all individuals within its domain means that it has the authority to pass laws that all can reasonably accept. The state may thus recognize the obligations of other actors as well, but it does so not as the "originator" of these obligations, but rather as the institution best placed to ensure their public recognition and institutionalization by performing its role as the legitimate enforcer of public obligations. 55 The state thus retains a unique character and role in protecting fundamental rights, even though the domain of agents with public human rights obligations is expanded.

Close examination of fundamental rights requires a rethinking of the sharp boundaries that are often drawn in international and domestic law between the public and the private. The very idea of rights requires a conception of the obligations of agents that is not artificially restricted, but focused on the primacy of ensuring that individuals' fundamental interests are realized. Indeed, this rather basic idea has important implications for the agents, institutions, and structures we create around us. In turn, a focus on these obligations requires us to think very carefully about the distinctive nature of each of these agents, which will in turn have implications for the allocation of obligations between them. I argue that there is a continuum between the public and the private nature of these agents, with many having a dual nature. This rather complex picture challenges our traditional taxonomies and,

55. I only here consider the "public" nature of the state in relation to those within its territory; arguably, at the international level, states may act to pursue the self-interest of those who lie within its domain. See Onora O'Neill, Bounded and Cosmopolitan Justice, 26 REV. INT'L. STUD. 45, 51 (2000), for a discussion of Rawls' conception of states as inevitably condemned to pursuing rational self-interest. In certain law and economics literature, the state is also, sometimes, conceived as a "corporation" with its citizens as "shareholders" within that corporation. See JACK L. GolDSMITH \& ERIC A. POSNER, THE LIMITS OF INTERNATIONAL LAW 5 (2005) ("[S]tate interests can be identified . . . , and through various domestic institutions states can and do maintain their corporate identity."). See generally ANDREW T. GUZMAN, HOW INTERNATIONAL LAW WORKS (2008) (applying rational choice assumptions to state action and compliance within international law to demonstrate that states "seek to maximize their own gains or payoffs"). 
more importantly, places the realization of fundamental rights as being at the core of what international law should be about. As such, it affords the opportunity to recognize the particularities of differing agents and their role in realizing fundamental rights, and to adopt increasingly effective modalities to realize them. 